\title{
CHALLENGES FACING THE WORLD TRADE ORGANISATION: AN OVERVIEW
}

\section{Gary P. Sampson ${ }^{*}$}

* Professor of International Economics, Melbourne Business School, Melbourne University, Australia 3010; email G.Sampson@mbs.edu. Former Director at both GATT and WTO then Counsellor in the Office of the WTO Director General. I would like to thank Peter Lloyd and Serafino Marchese for most helpful comments; as well as, Jan- Eirik Sorenson and Edwini Kessie.

This is the author manuscript accepted for publication and has undergone full peer review but has not been through the copyediting, typesetting, pagination and proofreading process, which may lead to differences between this version and the Version of Record. Please cite this article as doi: $10.1111 / 1467-8462.12301$ 


\section{Introduction}

Tensions are certainly running high on many fronts of the world trading system. The implications for international trade, international relations and eventually world peace are unknown. The source of tension is multifaceted. A common thread is discriminatory trade restrictions taken unilaterally, absent of international scrutiny, and followed by retaliatory measures. Unfair practices concerning intellectual property, gaining trade advantages via state owned enterprises and dumping are also on a long list. The result is that sufficient conditions now exist for a serious degeneration of trading relations creating a downward spiral and launching a true trade war.

History tells us a downward spiral can be avoided if trading relations are based on rules agreed to by all trading partners, enforced by an effective compliance mechanism and fully respected by governments. This has been the experience of the multilateral trading system for over seventy years; from 1 January 1948 with the creation of the General Agreement on Tariffs and Trade (GATT), and from 1995 the World Trade Organisation (WTO). ${ }^{1}$ Martin Wolf, expressed the majority view at the time of his writing: 'the multilateral trading system at the beginning of the twenty first century is the most remarkable achievement in institutionalized global economic cooperation that there has ever been.' (Wolf 2002, p. 183) Fast forward to current times. Asked if his proposed trade policies would contravene the WTO Mr. Trump replied: 'It doesn't matter ... if that's the case we're going to pull out. These trade deals are a disaster. The WTO is a disaster.' (Trump 2016)

In what follows, challenges facing the WTO are identified along with suggestions as to what reforms could assist in dealing with them. ${ }^{2}$ In my view, reform will not come as a 'big bang' as proposed, for example, by President Macron: 'what is required is a complete overhaul of the regulations which structure international competition'. (Macron 2018) This will not happen. I will argue that what is required is a 'bottom up' approach. Simply put, much of the WTO works well but the real risk is to lose what works in the process of reform: in other words, 'don't throw the baby out with the bathwater'. Further, only governments can reform the WTO. There can be expert group recommendations and advice from individuals on how the WTO should be reformed, but reform can only come from within: in other words, the WTO must 'pull itself up with its own bootstraps'.

There are two recurring themes in the following. First, the critical importance for Australia of a wellfunctioning multilateral trading system for both economic and geopolitical reasons. Second, for a variety of reasons, Australia is particularly well placed to play a leadership role in advancing proposals for reform. I will first overview the characteristics of the multilateral trading system that are relevant for the discussion of the challenges that follows. The paper closes with a conclusion. Given the rapidity with which trade policy changes (just a tweet away), attention has been focussed on the more systemic challenges facing the WTO.

\section{A remarkable achievement?}

\subsection{Trade liberalisation and membership}

In March 1948, 56 countries signed the Havana Charter, an agreement to create an International Trade Organisation (ITO). The ITO was to have a wide policy breach dealing not only with international trade but many other important policy areas. The ITO never came into force; it was not ratified by the US 
Senate arguing it would be too invasive in internal affairs. Because of the US rejection, no other state ratified the ITO. Elements of the Charter would later become the General Agreement on Tariffs and Trade (GATT); an interim agreement awaiting the eventual creation of an ITO. The wait was long; it took almost half a century to the create the World Trade Organisation (WTO).

The General Agreement on Tariffs and Trade (GATT) was born in Geneva in 1948 as an agreement between 23 governments to liberalise tariffs and remove quantitative restrictions for trade in goods. In today's parlance, the GATT evolved as a plurilateral agreement and emerge almost half a century later as a multilateral institution; namely, the WTO with 125 members. ${ }^{3}$

The WTO today has a vastly expanded mandate with 164 members and rules covering 98 per cent of world trade. That there are 22 countries waiting to join is not surprising. Countries that have undertaken the reforms required to join the WTO have grown 20 per cent faster than the overall world average for the past twenty years. (Wolff Alan 2018) World trade has increased 262 times in value terms (US\$) since 1948 and 60 times real terms. The average growth of world trade over the past 20 years is 5.3 per cent per annum. As world trade has increased faster than world production in virtually every year since 1947, it is an arithmetic truism that the share of international trade in world GDP has increased; from just $18 \%$ in 1947 to $56 \%$ in 2017. All but a small fraction of world trade takes place smoothly according to WTO rules; at the rate of AUD\$ 3.2 billion per hour.

In 1948 world tariff averages for industrial products were around 40 per cent. They are 4.2 per cent today. Importantly, tariffs have been 'bound' at a maximum rate allowable under WTO agreements. The average bound rate for Australia is 9.9 per cent with 97 per cent of its 6,186 tariff lines bound. Like other countries, Australia applies a rate which is equal to or lower than the bound rate (i.e. the applied rate) with the difference being the 'binding overhang.' This provides a measure of flexibility to increase rates when considered necessary by the government. It also provides negotiating room to further lower bound tariffs when exchanging market access possibilities. Australia's applied is $2.5 \mathrm{per}$ cent giving it the largest 'overhang' (7.4 per cent) of any developed country. From a commercial and negotiating perspective, binding tariffs is as important as reducing them. Uncertainty is regularly cited by business as the most significant non-tariff barrier to trade. Australia is the $23^{\text {rd }}$ world largest exporter of goods and has of 1.2 per cent of world total trade. The corresponding figures for trade in services are $24^{\text {th }}$ with 1.1 per cent of world total.

While there has been success in reducing tariffs on manufactured goods trade the case of agriculture has been disappointing, particularly for Australia. While agriculture had been covered by specific GATT disciplines, the Uruguay Round was the first-time agriculture was addressed comprehensively in a trade round. The Agreement on Agriculture made progress in requiring that quotas and other nontariff barriers be converted into (often very high) tariffs, in capping and reducing domestic support assisting production, and in capping and requiring some reduction in export subsidies. The reality is, however, that the Agreement on Agriculture has in practice impinged little on policy and particularly the EU and Japan continue to make their markets particularly difficult to access.

\subsection{Rules}


The WTO is a rule based organisation. Its rules are embodied in its many agreements. The most important rule prohibits WTO member governments from discriminating against other members when trading like products of goods and services. 'Most favoured nation' (MFN) treatment means the best treatment given to any country must be given to all WTO members. The other pillar of nondiscrimination is 'national treatment': once a product or service is within the borders of a WTO importing country, it cannot be discriminated against when competing with a domestically produced like product or service. Preferential Trade Agreements (discussed below) constitute an exception to the rule of non-discrimination. Preferential trade means discrimination against non-parties to an agreement which is the antithesis of non-discriminatory trade. Preferential Trade Agreements (PTAs) are permitted by the WTO if certain conditions are met: including not raising barriers overall to those outside the PTA and covering 'substantially all' trade between the parties.

A 'rules-based trading system centred on the WTO is fundamental to Australia's interests. Strong rules that help constrain the exercise of coercive power contribute to global security.' (Australian Government 2017 p.82). Why is this so important for Australia? It responds to the question of if there is a trade war between China and the United States, who should Australia side with? Is such a trade war a realistic possibility? According to President Trump: 'Trade wars are good, and easy to win.' (Trump 2018a). In a well-functioning rule based system, Australia should not have to side with either China or the US. It wouldn't be necessary. Australia's major trading partners are also WTO members; including, of course, China and the US. Both countries have agreed to trade according to rules and procedures they have negotiated and adopted. Adjudication is not determined by commercial or military might but by a mutually agreed dispute settlement system. Although rule-governed trade may not guarantee peace, it does remove a potent source of conflict.

\subsection{Enforcement}

Rules mean little if they cannot be enforced. Here the WTO is unique in the mosaic of international institutions. WTO law is not 'best endeavours'; it is 'hard law'. In the event of a dispute, WTO members have agreed to forgo a degree of national sovereignty for their collective good and pay a significant price if they do not respect their obligations. The preferred outcome of disputes is agreement through consultation; approximately one third of WTO disputes have been settled at this stage. Failing to reach agreement, governments can request a panel to adjudicate to see if the member complained against has failed to respect WTO law. The panel ruling can be referred to an Appellate Body which can review the Panel finding in the light of existing evidence to decide whether the ruling is legally correct.

If it is found that WTO rules have not been respected, the defending party must bring its offending laws into conformity with the WTO requirements. If the defendant is not able to do so, it may negotiate with the complainant and agree to pay compensation in the form of roughly equivalent market access on another product or service until its laws are brought into conformity. If no compensation is agreed, the use of retaliatory trade sanctions may be requested by the complainant and authorised by the membership of the WTO. There have been 561 disputes brought to the WTO. Australia has been a complainant in 8 cases, a respondent in 16 cases (five of which relate to plain packaging of tobacco) and a third party (registered as having a substantial interest) in 104 cases. By way of comparison, the United States has been a claimant in 122 cases and a respondent in 147. For 
the European Union the corresponding figures are 99 and 85. The United States has won 87 per cent of the cases it has brought to the WTO.

\subsection{Negotiations, Rounds, and Agreement}

As the trading system is in a constant state of evolution there have been eight periodic 'rounds' of negotiations concluded under GATT to ensure trade rules remain relevant. The ninth round was launched by trade ministers in November 2001 - the Doha Development Agenda (DDA) - also known as the Doha Round. The objective was to further liberalise trade, update, extend and strengthen WTO rules, and to address concerns that many developing countries had not benefitted from world trade growth. These negotiations were to be completed within three years of being launched but have virtually collapsed. In its almost 25 years of history, the WTO has not managed to conclude a single round.

The credibility of the WTO has been badly damaged as a result. Drawing the Doha Round negotiations to a conclusion among 164 countries has not been easy. Eighteen years of intense negotiations cannot be crystallised due to a very impractical requirement that in 'rounds' of negotiations: 'nothing is agreed until everything is agreed'. While governments do not vote, all 164 WTO governments must reach consensus on all aspects of the negotiations to close off a round of negotiations. Such a consensus has not been reached in the case of the Doha Round. This has proven to be increasingly difficult with the growth in numbers of the membership including countries with different stages of economic development, political systems, and negotiating priorities. Not surprisingly, this has proven to be an encouragement to move discussions on some issues outside of the WTO. An alternative means of negotiations is clearly needed to meet the objective of restoring the WTO its appropriate role in global governance.

\subsection{WTO at work}

The WTO is also an international bureaucracy which unlike others, has no power of its own. The WTO is small when compared to the International Monetary Fund, the World Bank, the OECD and other well-known and respected institutions. The WTO is quite independent of the United Nations. The total budget of the WTO is AUD269 million. It is financed via national budgetary contributions which are determined according to a country's share of world trade. And it comes cheap. Australia has 1.3 per cent of world trade so its annual contribution is 1.3 per cent of the total budget i.e. AUD 3.6 million. The IMF on the other hand has budget of US2.2 billion; its travel budget alone far exceeds the total budget of the WTO.

The Secretariat, with offices only in Geneva, has 634 regular staff and is headed by a Director-General. Since decisions are taken by Members only, the Secretariat has no decision-making powers. Its main duties are to support the various councils and committees, to provide technical assistance for developing countries, to monitor and analyse developments in world trade, to provide information to the public and the media and to organize the ministerial conferences. The staff is highly competent, well respected and experienced; based on my own experience it has the capacity to play a much more proactive role (see below). 
There are numerous WTO committees, councils, working groups, negotiating groups meeting on a regular basis. There are in fact about 60 of them. While day-to-day activities are undertaken by delegations based in Geneva, Committee and other meetings may also involve officials from capitals. However, the extent of capital-based participation varies substantially across committees and working parties/groups. Unlike committees in many other organisations, those in the WTO generally serve a useful purpose. For example, thousands of questions are asked in committees dealing with product standards and safety, regulation, labelling, agricultural subsidies, and trade remedies such as safeguards. Only an insignificant minority end up in the WTO dispute settlement body for adjudication. Take one contentious area: sanitary and phytosanitary measures (SPS) or food safety and animal and plant health. Since 1995, 15,257 measures have been notified to the WTO, with 434 concerns raised in the SPS Committee. Only 42 cases cite this agreement in requests for dispute consultations.

\subsection{Liberalising negotiations: the reality and Australia}

In practice, most WTO negotiators are basically mercantilist. Liberalising negotiations are not seen as an exchange of national 'benefits' via cheaper goods and services for consumers and inputs for manufacturers. Reducing tariffs is a national 'costs' described as a 'concessions' to a trading partner (as the Oxford dictionary puts is ... 'a concession is the act of conceding or giving something away').

This has not been the approach of Australia which has moved from being the most protected of all OECD countries in the 1960's (along with New Zealand) to one of the most open. It is a text book case in unilateral trade liberalisation with content and timing based on national interest. This 'go it alone' approach characterised particularly the Hawke-Keating era. ${ }^{4}$ According to Prime Minister Hawke in 1985: 'an essential requirement I believe is for trade policy to be seen more as an integral part of broad domestic economic management and less exclusively as the subject of international negotiations' (Snape et al. 1998, p. 5). Being an integral part of broad domestic economic management has been backstopped by the Productivity Commission and its prior incarnations (Tariff Board, Industries Assistance Commission (IAC) and Industries Commission). These institutions stressed that tariffs, quotas and other industry assistance should be evaluated in an economy wide perspective through public inquiries to identify transparently who are the gainers and losers from industry assistance. Following Australia's unilateral liberalisation (motor vehicles, textiles and clothing, footwear, etc.) and ensuing growth performance over three decades, its voice as a model of unilateral liberalisation is listened to by WTO member countries.

And the IAC has been effective in the past at the multilateral level. In proposing greater transparency for GATT processes at the GATT Ministerial meeting in Montreal in 1988 former Chairmen, Bill Carmichael and Alf Rattigan, stressed the need to: “... recognise the interactive relationship between the 'external' dimension of trade policy (agreed to through multilateral cooperation) and those which belong to domestic policy (domestic adjustment and efficiency)". The IAC convinced the Department of Foreign Affairs and Trade to make the case in Montreal for ministers to report regularly on all aspects of their trade policy. The outcome was the adoption by consensus of the Trade Policy Review Mechanism which has been a pillar of GATT and WTO since 1988. (Carmichael 2005).

\section{Paradigm shifts}


The future of the WTO as a force of global governance depends in large measure on how the WTO responds to four paradigm shifts in world trade: the proliferation of Preferential Trade Agreements $(\text { PTAs) })^{5}$, the growth of global supply chains (GSCs), and the lack of willingness to negotiate in a multilateral context given the demands of negotiating partners.

\subsection{Preferential Trade Agreements}

As noted, PTAs are characterised by discrimination against non-parties. Their growth in numbers is astounding and has now reached around 460. Every WTO member belongs to at least one PTA and some as many as 38 (i.e. the EU). While some are of limited importance in commercial terms (e.g. Denmark Faroe Islands Free Trade Agreement), others are vast to say the least (e.g. NAFTA and the European Union). Even though they are discriminatory in nature, PTAs are an important instrument for countries wishing to reduce barriers to trade and pursue deeper integration They are permitted by the WTO if they meet the WTO conditions of not raising barriers to non-parties and are not simply sectoral agreements but cover substantially all trade.

A significant development is for governments to attempt to negotiate 'mega' PTAs; the Trans-Pacific Partnership (TPP) and the Trans-Atlantic Trade and Investment Partnership (TATIP) provide examples. So too does the Regional Comprehensive Economic Partnership (RCEP), an ASEAN-centred proposal which includes Australia. ${ }^{6}$ Recent PTAs increasingly extend beyond tariff reduction to matters not subject to WTO rules; foreign investment, cross border data flows, the digital economy, and various dimensions of domestic regulation (e.g., competition policy; public procurement; regulatory cooperation). The motivation is to obtain in a PTA what is important from a commercial perspective but not available in the WTO.

Australia has been actively negotiating PTAs; it has PTAs with ASEAN and nine individual countries which together account for 64 per cent of Australia's total trade. From a national perspective the Government considers PTAs to be useful, but a second best to working within a stronger WTO: Since 'comprehensive deals in the World Trade Organization (WTO) are unlikely, we will pursue new opportunities for our companies and strengthen trade rules through bilateral and regional free trade.' (Australian Government 2017, p.5).

Have Australia's PTAs been beneficial? The view of the Productivity Commission is that the net benefit is small due to trade diversion, a less efficient allocation of resources and administrative and compliance costs. Rules of origin, which are an intrinsic part of PTAs add to the cost of trade and raise complexity. The Productivity Commission adds that in terms of intellectual property, poor consultation and transparency have led Australia to sign international agreements that have sometimes worked against its own interests. (Productivity Commission 2017, p.76) The United States Trade Representative (USTR) has a very different view on the usefulness of the United States-Australia Free Trade Agreement: For USTR Australia is 'a model for what a mutually beneficial trade agreement can be'. (USTR 2018, p. 6) Presumably this is linked to the current US administration thinking that trade surpluses are good and deficits are bad. In 2017, the United States had a US\$14.6 billion surplus with Australia in goods trade and a US\$14.7 billion surplus services trade.

\subsection{Global Supply Chains}


A second paradigm shift is the expansion of integrated productive activities involving design, production, marketing, distribution and customer support spread across various countries as 'global supply chains' (GSCs). They involve multiple firms and geographic locations producing goods and services with labour and materials assembled in another country, and ultimately consumed all over the world. As a label of origin, 'made in the world' would be appropriate.

Viewing world trade from this perspective has important implications for trade balances as conventionally measured. What is common to GSCs is that each stage of the production process adds value to the final good or service when sold on the global market. Recognition of this fact is not new. Grubel and Lloyd (1971) drew attention to measuring trade in terms of gross value distorts the picture of bilateral trade balances by double-counting trade flows and attributing production to the wrong geographical locations. It is effectively saying that the entire value of an export could be accounted for by the last country in the supply chain. This has important implications from a policy perspective. While China has a \$541 AUD billion trade surplus with the US, much of the value of final goods is only at the assembly stage. The trade surplus of China with the US would be reduced by 25 per cent if double counting was corrected for.

The efficient operation of GSCs requires not just low barriers to trade but a stable and predictable policy framework. ${ }^{7}$ Do GSCs need a global response? Is the WTO adequately equipped to deal with them? WTO agreements are already present at many critical points of the supply chain (e.g. Technical Barriers to Trade, Sanitary and Phytosanitary measures, Trade in Services, Intellectual Property, Trade Facilitation, Information Technology). The question is, based on the experience of PTAs and GVCs, what are the priority areas that could usefully be negotiated under the auspices of the WTO. Further, what form could they take and what would be the benefits? This is addressed in the next section.

\subsection{Willingness to negotiate}

It is evident from the extraordinary growth of PTAs that there is no lack of willingness for governments to negotiate trade agreements. The paradigm shift is the unwillingness of governments to negotiate multilateral agreements, where they find the demands of negotiating partners to be unreasonable. This shift is certainly at least partially a response to the failure of the Doha Round; is there an alternative way of negotiating that can fill policy gaps in a non-discriminatory manner? One solution, dating at least from the creation of GATT in 1948, is moving from a plurilateral agreement and eventually progressing to a multilateral accord. There are two models.

\subsubsection{Open Plurilateral Agreements}

In this case the subject matter is decided upon by a subset of the WTO members. Any WTO member can join the ongoing negotiations or when the agreement is finalised. Non-discrimination can be achieved if the sub-set of countries offer the benefits of their plurilateral agreement to all WTO members. 'Free riding' by non-parties could be avoided by first requiring a 'critical mass' of support (80-90\%) before extending the benefits on an MFN basis. As such, the two-step approach (first plurilateral then multilateral) would lead to a non-discriminatory multilateral agreement within the WTO. Such agreements do not require consensus to be incorporated into the WTO - if Members decide to join an open plurilateral agreements by improving market access for others they can inscribe 
the trade liberalising provisions of the agreement into their schedules. In this process, the agreements become part of the WTO and are serviced by the WTO Secretariat.

An example is the WTO Information Technology Agreement (ITA), concluded by 29 participants at the Singapore Ministerial Conference in December 1996. Since then, the number of participants has grown to 82 , representing about 97 per cent of world trade in IT products. The participants are committed to eliminating tariffs on IT products covered by the Agreement. In December 2015, over 50 members concluded the expansion of the Agreement, which now covers an additional 201 products valued at over $\$ 1.3$ trillion per year.

\subsubsection{Closed Plurilateral Agreements}

Closed plurilateral agreements are negotiated on a non-MFN basis where benefits are restricted to participants. Closed plurilateral agreements are binding on those Members that have accepted them and do not create obligations or rights for those that have not. For them to be fully within the WTO with access to the dispute settlement system and secretariat services, they must be adopted by all WTO members 'exclusively by consensus.'

The Agreement on Government Procurement (GPA) is an example of a closed plurilateral agreement which is fully within the WTO. Australia has just acceded; there are 47 WTO members (counting EU 28-member states individually). Ten WTO members are in the process of acceding. The GPA parties have opened procurement activities worth US\$1.7 trillion annually to international competition. The GPA comprises the text of the Agreement and schedules of commitments. Creating agreements like the GPA - adopted based on consensus would be a very tough call in the current economic and political climate.

\subsubsection{Way forward}

'Australia should continue to invest effort in the development of plurilateral or sector-specific agreements, especially those that allow most favoured nation treatment and that can be incorporated into the World Trade Organization.' (Productivity Commission 2017, p.94). A stumbling block has been an agreed process to advance open plurilateral agreements. A starting point could be to identify policy areas of GSCs and PTAs which are not presently covered by WTO rules. A great deal of work has been done by the World Bank, the WTO secretariat and academic circles identifying provisions in PTAs that go beyond those of the WTO. ${ }^{8}$ The technique employed is to identify 'WTO-plus' and 'WTO-X' measures. WTO-Plus measures are covered by WTO disciplines but the PTA commitments are more demanding than the WTO. The 'WTO-X' term applies to disciplines that are not found in WTO agreements thus creating new rules rather than extending or deepening existing disciplines.

Australia could propose that the WTO secretariat create such a list of priorities based on the technical work already undertaken. It could be taken as a starting point for discussion by governments. To be realistic, given the current mood of distrust in the WTO, even reaching agreement to assign this task to the secretariat would not be an easy task. This is most unfortunate as a neutral list proffered by the secretariat would kick the ball into the ring for serious discussion. My own experience as Director of the GATT Division dealing with trade in services for the duration of the Uruguay Round was that unlike established negotiating topics, governments were quick to seek the ideas of the secretariat in this new 
area of services. One important breakthrough was agreement on what constitutes 'trade in services': it came in the form of 'modes of delivery'. Governments requested a secretariat paper on how to define trade in services; the result was based on article published in an academic journal. It was agreed to relatively quickly by all governments. (Sampson and Snape 1985) There were numerous examples of 'breakthroughs' during the 9 years of negotiations leading up to an agreement to liberalise trade in services. These include questions such as what are barriers to trade in services, how are different sectors affected by these barriers, and what should be the sectoral coverage of the agreement, how to exchange concessions when the economic activities are so different. These questions were successfully addressed with neutral documentation leading to constructive discussion among delegations. As a general proposition, the secretariat is an underutilised resource for governments.

While governments would struggle with this approach today, Australia is well placed to promote an initiative along the lines of structuring a process leading to open plurilateral agreements in conjunction with other RCEP countries. Australia has a history of negotiating with RCEP members; it has PTAs with China, Japan, Malaysia, New Zealand, Singapore, South Korea, and Thailand. It is also negotiating agreements with Hong Kong, India and Indonesia. The RCEP provides a platform for members to promote their shared interests in freer trade by initiating plurilateral negotiations in areas of common interest. Even if a core group of Australia, China, Japan, South Korea, and key Southeast Asian nations engaged in the process it would have a major effect on the global trade policy environment.

\subsection{Developing Countries and WTO}

Speaking at the inaugural session of the United Nations Conference and Development (UNCTAD) in 1964, Che Guevara advised developing countries, among other things, not to "break the ranks of numerically superior forces' when it came to international trade negotiations. (Che Guevara 1964) One of the principal outcomes of the conference was the creation in June 1964 of the Group of 77 developing countries which would act collectively over the coming decades in both UNCTAD and GATT. The objective was to achieve the maximum legal flexibility in trade agreements of a generic nature for all developing countries alike irrespective of their national priorities and resources.

In the early days of GATT, the 'Quad' countries (US, EU, Japan and Canada) dominated the decisionmaking process. In large measure, developing countries were a passive and ill-informed minority. There has been a paradigm shift. Two thirds of WTO membership comprise developing countries, many of which are both active and well organised in negotiations. A second shift is the recognition that their national interests do not always coincide; to pursue different development strategies they require different degrees of policy space and legal flexibilities to implement their 'appropriate' development strategy.

\subsubsection{Legal Flexibility}

The original thinking on the part of GATT members was that equal treatment of un-equals is unfair. The need for legal flexibility to adjust for this unequalness created the concept of "special and differential treatment" which generally absolved developing countries from undertaking the same obligations as developed countries. ${ }^{9}$ The development paradigm was a belief that poor countries can develop by heavily protecting domestic industries, producing for the domestic markets and 
substituting for imports. This required infant industry protection, flexibility in the use of balance of payments measures, non-reciprocity in trading tariff concessions, and preferential market access for manufactured exports.

The use of, and need for, special and differential treatment instruments has both expanded and changed greatly. At present there are 148 special and differential treatment provisions in WTO agreements. These are directed at increasing trade opportunities, safeguarding certain interests, flexibility in the implementation of commitments, permitting otherwise WTO-unacceptable policy instruments, and granting of technical assistance. The WTO further acknowledges special treatment for least-developed countries, designated as such by the United Nations (UN). There are currently 47 UN listed least-developed countries (LDCs), 36 which have become WTO members. Eight more are negotiating to join the WTO. Over and above the provisions in WTO agreements, 16 Ministerial and General Council Decisions accord special treatment to developing countries and LCDs. The provisions are both mandatory and non-mandatory.

It seems reasonable that the WTO provide all countries - developed and developing alike - with the necessary policy space (or legal flexibility) to implement the most appropriate policies from a national perspective (antidumping duties, countervailing duties, safeguard measures, national security etc.). In accordance with this logic, developing countries should be accorded the legal flexibility to pursue their appropriate development strategy. Thus, a logical starting point in creating legal flexibility is to have a clear vision of what is the 'appropriate' development strategy for developing countries. But who decides what is appropriate; what domestic policy space is required to implement it; what legal flexibility is required; and what is the nature of the measures that are best suited to achieve the desired result for developing countries?

The simple reality is that the term "developing countries" masks very different characteristics and needs of developing countries and therefore appropriate strategies. Any development model is inextricably linked to a wide variety of country characteristics: natural resource endowments, cultural heritage, characteristics of leadership, institutional and other arrangements. A principal reason for lack of effectiveness of many special and differential flexibilities is that they are generic to all developing countries and neglect the country specificities. What adds some confusion is that developing countries that are eleogible for legal flexibility were never named in the GATT and simply referred to in GATT texts as economies that can sustain only "low standards of living" or are in "the early stages of development". Not only is this language clearly open to interpretation, the process of 'being' a developing country is a self-selection process. A country was a developing country if it desired to be considered as such.

What constitutes an 'appropriate' development strategy lies at the heart of the need for legal flexibility. Even when the country characteristics are known, what is an appropriate policy has too often been held hostage to the vacillating whims of mainstream development economists. Anne Krueger, in her Presidential Address to the American Economic Association, remarked that early trade and development theories and policy prescriptions were based on some widely held stylized facts and premises about developing countries. These, she says, were "a mixture of "touristic" impressions, half-truths and misapplied policy inferences. (Krueger 1997 p.3) While there was a recognition of the 
differences in resource endowment and other features of developing countries, the acknowledged differences were thought to be overwhelmed by the common characteristics of underdevelopment.

The failure of the policy of providing legal flexibility for developing counties has not gone unnoticed. Governments agreed in the declaration launching the Doha Agenda that all special and differential treatment provisions should be reviewed with a view to making them more 'precise, effective and operational'. Unfortunately, as with the Doha Round itself, and despite dozens of country submissions as proposals, no progress has been made in meeting this objective. This is most unfortunate, even more so as with the advent of the Uruguay Round, the goal of absolving developing countries from the normal obligations of WTO agreements, has been overtaken by the objective of "increasing the participation of developing countries" in the world trading system. This has become synonymous with developing countries forgoing legal flexibility and undertaking more commitments in relation to trade liberalization.

From a policy perspective, what should be targeted is the negative connotations surrounding the term "graduation" being increasingly replaced by a more positive approach in which the reduction of legal flexibility is traded for increased discipline, improved market access through greater competitiveness, and a negotiated reduction in remaining trade barriers. This should then be coupled with a new role for developing countries in the multilateral trading system as the guardians of openness, resisting moves by more developed countries to invent and apply new trade barriers.

\subsubsection{Growing importance}

Two thirds of WTO members are developing countries. The days of dominance by the Quad countries are long gone. The importance of developing countries has increased not only in terms of numbers but also economic significance. In 2017 developing countries' merchandise imports grew faster in value than those of developed economies increasing by 13 per cent; exports (totalling US\$ 7.43 trillion) grew by 12 per cent. Developing countries now have a share in world trade of 43 per cent. More than $50 \%$ of their exports go to other developing economies and trade between developing economies is over $20 \%$ of world merchandise trade. Developing economies accounted for 31 per cent of world services exports and 38 per cent of imports with a $34 \%$ share of world trade in commercial services. Consequently, the weight of developing countries in the WTO is now not only considerable, they are prepared to use it as the following example makes clear.

At the 2013 Bali ministerial meeting, all 160 WTO countries signed off on a multilateral agreement (the Trade Facilitation Agreement) to cut red-tape, reduce corruption and speed up supply chains. According to the WTO Director General, the Bali Agreement would boost the global economy by \$US1 trillion per year and generate 21 million new jobs. The OECD estimated that trade costs would be reduced by over 15 per cent in poor countries and more than 10 per cent in developed ones. However, the TFA hit a brick wall. Consensus was required to legally incorporate it as a plurilateral agreement into the WTO. India reneged on its agreement in Bali insisting that it would not agree until its own nationally preferred solution to the stockpiling of food for security purposes was adopted. While both food stockpiling and the TFA were under discussion in Bali, there is no formal, legal or substantive linkage between them. While this must seem bizarre to many, it's just one more manifestation of the shortcomings of the so-called "consensus rule" in WTO negotiations where "nothing is agreed until 
everything is agreed". The result was that India, certainly a populous nation, but accounting for just 1.5 per cent of world merchandise trade and contributing 1.8 per cent to the WTO budget, had the capability to block an agreement worth USD 1 trillion per year.

\section{Remedies and President Trump}

\subsection{Contingent Protection}

While binding tariffs, and applying them equally to all trading partners are key WTO rules for trade in goods, barriers may be raised contingent upon meeting certain conditions; these contingent measures are mainly contained in the WTO Antidumping Agreement, Subsidies Agreement, and the Agreement on Safeguards. (WTO 2002). It is paradoxical that contingent measures, backed by national laws, which largely mirror WTO requirements lie at the heart of the current escalating animosity in trade relations. To appreciate the source of current conflicts - and therefore the policy response - requires unravelling the relationship between national laws, WTO obligations, the trade restricting measures, and the response to them.

While the Trump administration has controversially made use of key US domestic laws relating to trade, it is far from alone. The US President has considerable authority over trade policy. This has evolved over time. After the disastrous Smoot-Hawley tariffs in 1929 Congress ceded its constitutional authority on trade to the President. Secretary of State Cordell Hull was granted the power to negotiate trade liberalising agreements - including the GATT. The assumption was that while Congress represented the constituencies of elected politicians, a President would act in the national rather than narrow sectional interests to expand trade. And for decades executives of both parties did. George H.W. Bush negotiated NAFTA, Bill Clinton pushed it through Congress, and the US was a driving force behind GATT and then the WTO under both Democratic and Republican Presidents. Donald Trump appears to be taking that authority and using it for protectionist, rather than trade-opening purposes. For example, invoking 'threat of national security' provides enormous latitude to define a nationalsecurity trade threat and virtually unlimited authority to impose a tariff or quota remedy.

\subsubsection{Anti-dumping ${ }^{10}$}

In an exchange with reporters on Air Force One in July 2017, President Trump remarked: 'Steel is a big problem. Not only China, but others. We're like a dumping ground, okay? They're dumping steel and destroying our steel industry, they've been doing it for decades, and I'm stopping it. It'll stop. There are two ways - quotas and tariffs. Maybe I'll do both." (Trump 2017a)

If a company exports a product at a price lower than the price it charges on its home market it is said to be 'dumping'. Dumping is not illegal and many countries welcome it in selected products. The WTO permits governments to apply anti-dumping duties if, following investigations, it is shown that dumping has occurred and has caused injury to the domestic producers producing the like product. The injury must be because of the dumped product. In other words, injury caused by other factors cannot be attributed to dumping. The dumping margin, calculated in percentage terms, is roughly the difference between the export price and the exporter's home market price. In the case of the US, the President does not have a direct role in anti-dumping proceedings. The complaining industry, rather than the government, typically initiates a dumping investigation. The Department of Commerce 
investigates whether the US price for the imported product is below the normal value benchmark. ${ }^{11}$ It calculates the 'dumping margin' (normal value minus export price) and the United States International Trade Commission (USITC) investigates whether the dumped imports have caused 'injury' to the domestic industry. More anti-dumping investigations have been initiated in the US than any other trade inquiry.

Inquiries into anti-dumping and the measures applied are reported to the WTO secretariat. Since the creation of the WTO, there have been 5529 initiations and 3604 instances of measures applied; 1153 in the steel sector. The US has applied 427 anti-dumping measures (21\% in the steel sector) against 43 countries. Australia has applied 151 measures, with 119 against China and 32 against other countries. The largest number of measures (656) have been applied by India. In terms of WTO disputes, US has been the main complainant in 60 anti-dumping cases; China a complainant in 15 cases, EU 18 and Australia 2.

While anti-dumping duties may well reduce the targeted imports, there can be important "knock on effects' with unanticipated outcomes. Exporters from countries of the same product and not facing anti-dumping duties may emerge to fill the gap; the restricted exports may be deflected to markets not subject to anti-dumping measures; or the producing companies in the country facing the duties may shift production capacity elsewhere. In short, ant-dumping duties may not meet the policy goals of the country imposing them. A recent example is instructive. The United States imposed antidumping duties on imports of solar panels from China in 2012 and 2015, and Taiwan in 2015. The duties had a restraining effect and imports from both China and Taiwan significantly decreased. By 2016, however, total imports had regained their 2012 level. New sources of supply emerged and the principal manufacturers in China shifted production abroad.

\subsubsection{Subsidies and Countervailing Duties ${ }^{12}$}

Most governments play a significant role in the economy, frequently in the form of subsidies affecting the international competitiveness of exports. Apart from export subsidies and subsidies contingent upon the use of domestic products over imported products (import substitution subsidies) which are prohibited, other types of subsidies are not WTO illegal. However, a government can impose a 'countervailing duty' (CVD) on subsidized imports found to be causing 'injury' to domestic producers producing like products. The complaining country must investigate to establish if the WTO conditions are met.

Under US law, US firms can petition the government to initiate an inquiry and the Department of Commerce investigates whether the foreign government has provided subsidies. The injury determination is analogous to antidumping and conducted by the USITC. Petitioners also frequently request 'simultaneous' antidumping and CVD investigations for the same product and exporter. As with anti-dumping actions, measures are applied to all firms in the industry of the targeted country. There are the same possible shortcomings as with anti-dumping duties. CVDs may well reduce imports from the targeted country but other exporters may emerge to fill the gap, the restricted exports may be deflected to markets not subject to CVDs, or production capacity may be shifted elsewhere. Like ant-dumping duties, CVDs may not always meet the policy goals of restricting imports. Since 1995 the 
US has applied 122 countervailing duty measures out of a total of 257 for all WTO members. Australia applied 15 CVD measures, 10 of which were against China. The EU applied 38 measures.

\subsubsection{Safeguards ${ }^{13}$}

An industry may request its government to take 'safeguard' action when imports seriously injury a domestic industry that produces the like or directly competing products. The rationale is that the 'injured' industry needs a breathing space to restructure and regain its international competitiveness. Such action is permitted under WTO law providing that there is a causal link between increased imports of the product and serious injury to a domestic company producing a like or directly competing product. Unlike antidumping or anti-subsidy investigations, safeguard measures are applied to all sources of imports. Another distinction is that under certain conditions the exporting country can seek compensation through consultations in the case of imposition of safeguard measures. If no agreement is reached the exporting country can retaliate by suspending equivalent concessions - for instance, it can raise tariffs on an equivalent amount of exports from the country that is enforcing the safeguard measure.

The USITC investigates petitions filed by domestic industries to determine whether an increase in imports is causing serious injury to the import-competing US industry. There is no allegation of 'unfair' trade needed to trigger the global safeguard-no dumped or subsidized imports-thus, there is no role for the Department of Commerce in the investigation. This is the third most-frequently triggered US trade law over 1995-2017. There is no WTO specific requirement for countries to have dedicated legislation on safeguards. In fact, Australia has no specific legislation for the imposition of safeguard measures. The Treasurer may refer matters to the Productivity Commission for inquiry. The Productivity Commission remains the investigating authority.

\subsection{Cases}

There is a variety of instances where contingent protection has been invoked for very different reasons. Here are some examples.

\subsubsection{Steel}

The steel industry has long been a thorn in the side of American presidents for quite some time. President Kennedy took a tough line. In April 1962, after American Steel increased steel prices, the Kennedy administration instigated a price-fixing investigation forcing them to rescind their price increases. This certainly won the hearts of some. 'Happy birthday Mr President. Thanks, Mr President. For all the things you've done. The battles that you've won. The way you deal with U.S. Steel. And our problems by the ton. We thank you so much.' (Marilyn Monroe 1962)

The steel industry was struggling in the 1990s. Officials blamed a surge of competition with cheap imported steel causing 'serious injury' to the domestic industry. In March of 2002, following an inquiry by the USITC, President Bush imposed 'safeguard tariffs' to permit the steel industry to adjust to foreign competition. Since safeguard action is applied to all suppliers of the targeted imports, it affects many countries; the 15-member European Union and seven other nations which were not the primary target of the restrictions complained to the WTO that the injury was due to a loss of US 
competitiveness not a surge of imports. The WTO ruled that the cheap imports were not the source of the US problem; if the US did not remove the import restrictions, European and other countries could legally impose retaliatory duties on $\$ 2.2$ billion of US exports. Initiated in 2001, this was the last US safeguard investigation conducted by the US until the very recent inquiry into solar panels. The outcome surely influenced the very recent choice of policy tools employed by the current US administration in restricting steel imports.

\subsubsection{Harley Davidson}

The use of safeguard measures to protect Harley Davidson is a different story. Harley Davidson accounted for 20 percent of the American market in the late 1970s, but by 1982 its market share had fallen to just 14 percent. USITC found that a 'surge' in imported heavyweight motorcycles imported from Japan was the source of 'serious injury' and argued for 'safeguard protection'. In 1983, President Reagan approved increased tariffs for five-years during which Harley Davidson improved its product design and manufacturing processes. Although the safeguard tariffs were due to expire on in 1988, Harley-Davidson requested that the safeguard relief be terminated in 1987.

\subsubsection{Solar Panels}

The restrictions on imports of solar panels demonstrates the interrelationship between policy instruments and highlights the interconnectedness of trade issues. The United States relies heavily on trade for its solar panels. In 2016, domestic manufacturers' market share was 11 percent. Solar panel prices have fallen by 84 per cent in the past decade, largely driven by technological change. The USTR puts it this way: 'After the initial imposition of anti-dumping and CVD duties in 2013 and again in 2015, Chinese solar manufacturing was offshored to other locations, including Malaysia and Vietnam. As a result, the import shares by country of origin have changed noticeably in recent years, but domestic manufacturers have consistently been crowded out. A factor in this rapid import penetration are allegations of forced technology transfer by Chinese parties.' (USTR 2018 p. 244)

With safeguard protection, the argument goes, the US industry can improve its productivity and international competitiveness. What is clear is that anti-dumping measures had not been effective in limiting the inflow of solar panels and intellectual property has been transferred inappropriately. Pursuant to an inquiry, USTR recommended that President Trump administer global quantitative restrictions as opposed to country-specific anti-dumping measures or CVDs due to the rapidly changing nature of available global supply. In January 2018, President Trump approved safeguard measures for solar panels and washing machines.

\subsection{Steel, Aluminium and National Security ${ }^{14}$}

'You see what's happened with our steel and aluminium industries. They're being decimated by dumping from many countries, in particular one, but many countries. They're dumping and destroying our industry and destroying the families of workers.' (Trump 2018b) While President Trump accusations were of dumping, presumably based on experience, he chose an alternative response: protecting national security. 
There is nothing in WTO agreements that prevents any member from acting to protect its national security. Claims for a security exception from WTO rules are 'self-judging'; members rarely challenge the use of protection for national security purposes, so it has rarely featured in formal dispute settlement either under GATT 1947 or the WTO. In one of the very few cases (Czechoslovak complaint concerning United States), the GATT panel put it this way: 'every country must be the judge in the last resort on questions relating to its own security. On the other hand, every Contracting Party [to the GATT] should be cautious not to take any step which might have the effect of undermining the General Agreement.' (GATT 1949 p. 1)

The national security option avoids the requirement to prove 'serious injury', calculate 'normal prices' and meet other contingent protection conditions. It may target one, several, or all countries. Governments have normally been hesitant to follow this route as there is little to prevent other countries from arguing that they too are justified to resort to similar exceptions; justifying import restrictions based on national security has been referred to as the 'nuclear option' of trade policy. (Bown 2017 p. 14) This is the least utilized US trade law over 1980-2016, with only 14 investigations, two of which resulted in trade restrictions. In April 2017 the US President requested the Department of Commerce to investigate whether steel and aluminium imports 'threaten to impair' US national security. In February 2018 the Department of Commerce found that steel and aluminium imports do impair national security; the President concurred and the tariffs were put into effect on in March 2018. The Trump administration did not wait for an industry petition and self-initiated the national security investigations. Self-initiated investigations have been very rare. There have only been 19 self-initiated investigations over 1980-2016-less than 1 percent of all investigations-and most of them were in the early 1980s. (Bown 2017 p. 14) The most recent self-initiated investigation was the 2001 Bush administration safeguard investigation into steel noted above. Apparently, the administration intends to increasingly self-initiate investigations. 'We have also begun the process of self-initiating trade cases, which speeds up the process of taking corrective action while allowing the Department of Commerce to shield American businesses from retaliation'. (Ross 2017\}. Firms, industry associations, and labour unions initiated 99 percent of trade investigations over 1980-2016. (Bown 2017 p. 14)

It seems unlikely that WTO members will accept the 'national security' reasoning of the US administration. Using the steel industry's own numbers, a minimal amount of domestically produced steel in the U.S. goes towards defence industries. During the exchange between President Trump and Members of the Republican Party, Senator Toomey advised the President: "I would just urge us to go very, very cautiously ... our defence needs consume about 3 percent of domestic steel consumption ... it's implausible to believe that we're not able to meet the needs of our defence industry ... Imports in 2016 were 16 percent of domestic consumption ... China was down to 2 percent of the 16 percent, so a very, very small portion.' (United States Government 2018, p. 6)

Picking up on statements like this, it not surprising, the national security measures are being challenged in the WTO by the affected countries: EU, Japan, China, Canada, Hong Kong, India, Mexico, the Russian Federation and others claiming there is no security threat. The fundamental problem is the under-capacity utilization of steel mills and aluminium plants where the goal is to maintain the domestic capacity at 80 per cent. Thus, European Union and others treat the US measure as a safeguard measure and have requested consultations with the US claiming inconsistency with WTO 
rules relating to safeguard protection. The logic of this is clear. If the action taken by US is safeguard action rather than defence of national security, the EU and other states can legally seek compensation or retaliate by imposing restrictions on US imports (which they have done) under the Safeguards Agreement.

\subsection{Policy Conclusion}

Based on this recent experience, there is clearly a need for WTO members to review the functioning of the provisions relating to contingent protection - and national security threats - in terms of their effectiveness in not only achieving national goals as well systemic threats to the multilateral system. But as we advise budding economists in our university classes, when it comes to policy reactions, look at the source of the problem to be dealt with and not the symptom. In the case of international steel, the source of the problem is overcapacity, perhaps contributed to by massive increases in production capacity in China, the symptom is increased tensions in the WTO, and the solution is a global understanding as to how to deal with the problem.

\section{China as a Non-Market Economy}

From 1990 to 2016 China's share of world manufacturing output increased from $5 \%$ to nearly $25 \%$, while its share of exports over that period rose from $2 \%$ to over $17 \%$. This rapid increase has given rise to increased scrutiny of China's economic policies and their consistency with WTO rules. One of the major challenges confronting the trading system is addressing tensions that have arisen because of gaps in the WTO rulebook that inhibit the ability of WTO members to determine which policies distort competition. There is clear evidence that China has not evolved into a market economy as anticipated at the time of its accession and this has important implications for the application of WTO law.

\subsection{China and WTO accession}

Expectations ran high at the time of the accession of China to the WTO; within 15 years it was expected to be a fully-fledged market economy and treated as such. According to Susan Schwab, the chief U.S. trade negotiator from 2006 to 2009, China joining the WTO has been "one of the most important events in modern economic history ... China has reduced tariffs on goods of great importance to US industry ... it has reduced or eliminated numerous non-tariff barriers, increased market access for international service providers and improved the transparency of its governmental procedures." 15 President Clinton, held the view that the China accession agreement "deals appropriately with the special and unusual characteristics of the Chinese economy: it addresses state trading; it bans forced technology transfer; ... it provides protections for Americans against import surges from China and from abusive export practices like dumping". (US Government 2001 p. 165) Charlene Barshefsky the chief U.S. trade negotiator from 1997-2001 stated that 'no agreement on WTO accession has ever contained stronger measures to strengthen guarantees of fair trade and to address practices that distort trade and investment.' (Wu p. 291) The "successes" listed above have in fact turned out to be the major complaints facing China in the WTO today. The expectation that China would evolve into a market economy have not been met; this has significant implications for many aspects of the work of the WTO. For this reason, it is important to look at the conditions imposed at the time of China's accession to place the current environment in context. 


\subsection{China: a non-market economy?}

China was an original contracting party to GATT and in 1986 formally requested its accession to the WTO. China acceded on December 11, 2001. China officially became WTO's $143^{\text {rd }}$ member. The accession agreement provides that China will be considered a non-market economy (due to state owned enterprises, subsidies etc.) unless Chinese producers can prove that market conditions prevail in their industry. The 'non-market' presumption was to expire 15 years after China's accession-i.e. on December 11th, 2016.

Non-market economy status for China is important particularly when looking at claims of dumping. Dumping investigations depend very much on what is taken to be 'normal value' in the exporting country. China having the status of a non-market economy means the importing country is not obliged to use the national normal value (price) in calculating dumping margins if the presumption is that price is not determined by the market. In this case, importing countries are free to use prices in third countries or construct the value in accordance with WTO criteria to determine 'normal value'; this could result in much higher dumping margins and punitive tariffs. More anti-dumping measures are applied to China than any other WTO member; that is, 25 per cent of all anti-dumping measures applied since the creation of the WTO and by 27 different countries. If China graduates to a 'market economy,' this change of status would make it considerably harder for nations to block imports they believe are improperly aided by Chinese government distortions.

According to the Chinese government considering China as a 'market economy' is 'a given' based on the accession agreement it signed in 2001. Most countries do not agree. On December 11, 2016, Beijing filed WTO complaints against the U.S. and E.U. for failing to consider China a 'market economy'. The argument of the respondents being that the China accession agreement did not guarantee China's market economy status by a certain date, but stated 'that importing countries will lose the right automatically to treat China as a non-market economy for anti-dumping purposes.'

Australia is one of the few countries that accords market status to China. This is to the chagrin of Australian steel and aluminium producers (BlueScope Steel) which argue they are being severely damaged by dumped products from China. There is increasing pressure from Australia's steel and aluminium manufacturers claiming Chinese steel and aluminium dumping. The EU, US, Japan and all other major economies have not accorded market status as they consider State involvement remains considerable. For example, the state retains a majority share in all but one of the 100 largest publicly listed companies in China. According to Wu (2016), WTO law is woefully inadequate to deal with China's economic model and the U.S. and its allies will increasingly seek recourse to non-WTO remedies to deal with their complaints.

In the light of China's extraordinary growth since its accession, there is need to give more precision to the concept of non-market economy, how to deal with state owned enterprise and the trade effects of government involvement in the market more generally. As the first country to grant China market economy status, and therefore more experience with the implications than other WTO members, Australia is well placed to propose a process to address this need.

\subsection{Intellectual property protection ${ }^{16}$}


According to President Trump: 'The theft of intellectual property by foreign countries costs our nation millions of jobs and billions and billions of dollars every year ... For too long, this wealth has been drained from our country while Washington has done nothing... But Washington will turn a blind eye no longer.' Trump administration officials have estimated that theft of intellectual property by China could be worth as much as $\$ 600$ billion. (Trump 2017b)

U.S. firms seek to enter China to take advantage of lower unit costs of labour, gaining access to its large domestic market, and making use of integrated supply chains for other markets. To access the Chinese markets, however, severe entry costs in the form of mandatory IP and technology transfer requirements are sometimes imposed. The WTO Trade Related Aspects of Intellectual Property Rights Agreement does not have provisions to deal with the complaints raised by the US; the US has resorted to national legislation.

The US Trade Act ${ }^{17}$ is designed to eliminate unfair foreign trade practices that adversely affect U.S. trade and investment. The USTR formally investigated allegations that, among other things, the Chinese government uses various means to compel foreign investors to transfer technology and intellectual property to domestic joint venture partners to secure regulatory approval for inward investment. Based on the findings, in March 2018, President Trump instructed USTR to apply tariffs to US\$50 billion on Chinese goods. Over 1,300 categories of Chinese imports were listed for the tariffs, including aircraft parts, batteries, flat-panel televisions, medical devices, satellites, and various weapons.

To avoid reactions such as this, there is a clear need for the WTO to establish how best to investigate whether forced transfer of technology should be regulated or if, as the Chinese seem to argue, it is a normal business practice. If it was a problem, they reason, it should have been registered in the China accession agreement. Underlying much of this concern is the fact that China has been clear about its desire to dominate key technological domains with long-term economic, military, and strategic significance. The 'Made in China 2025' targets include artificial intelligence, quantum computing, advanced semiconductors, 5G, the Internet of Things, robotics and electric vehicles. To fulfil the objectives requires access to the most advanced intellectual property in the world.

\section{Enforcement}

Sustaining the WTO dispute resolution mechanism - generally held to be a major global governance innovation - is critically important for the organization. Numerous proposals have been made by governments to improve the current process in the context of a review of the Dispute Settlement Understanding but there has been no agreement on the proposed reforms.

\subsection{Process}

A defining characteristic of the dispute settlement process is its quasi-automaticity: panel and Appellate Body reports are adopted unless there is a consensus against their adoption. The rule of negative consensus, greatly strengthened the WTO compared to the GATT where adoption - not rejection - required consensus. The losing party could always break the required consensus for adoption. Since 1995, over 547 disputes have been brought to the WTO, initiated by 50 members in relation to 20 WTO agreements. There were just 128 during the entire life of GATT (1948-94). Not all 
WTO disputes have required formal rulings, as a mutually agreed solution is always the preferred outcome. One third have been settled through consultation without progressing to the more formal Panel and Appellate Body stage. The US is the most frequent user of the dispute settlement mechanism: a complainant in 117 cases and a respondent in 114. It has lodged complaints against 29 counties, the most frequent being China. The United States has won 86 percent of the WTO cases it initiated. In contrast, China's success rate is 67 percent.

\subsection{Confidence in Decisions}

The WTO dispute settlement mechanism is an area of active debate. To be effective, there must be complete confidence in the outcome of its deliberations; this does not appear to be the case. Accommodating these concerns may be the greatest of all challenges facing the WTO. The first concern is that the Appellate Body has created rights and obligations that were never agreed to by WTO Members. The problem here frequently lies with governments; they have avoided closing off issues in negotiations leaving the settlement to litigation. 'Many are concerned that the WTO is losing its essential focus on negotiation and becoming a litigation centred organization. Too often members seem to believe they can gain concessions through lawsuits that they could never get at the negotiating table.' (Lighthizer 2017) This is linked to the GATT/WTO tradition of 'constructive ambiguity' where each negotiator can read into the text what is necessary to cover their own negotiating position, but where the legal meaning is ambiguous or imprecise.

Further, the interpretation of some terms in agreed texts places the panels and Appellate Body in a difficult situation. An example is the interpretation of the term 'like product' which appears 19 times in various WTO agreements. The colloquial usage of "like" means "similar". When I was responsible for the WTO Trade and Environment Committee there were ferocious debates as to when some imports are not "like" others and can be legally discriminated against. Is tuna caught in dolphin unfriendly nets like other tuna caught without damage to dolphins, and are eggs laid in battery cages like free range eggs? And like from whose perspective? From a gardener's perspective a slug and a snail are like products. For a French gourmet they are totally different. The Appellate Body has granted itself a great degree of discretion: "The accordion of likeness stretches and squeezes in different places as different provisions of the WTO Agreement are applied. The width of the accordion in any one of those places must be determined by the particular provision in which the term like is encountered, as well as by the context and the circumstances that prevail in any given case to which that provision may apply." (Sampson 2005 p. 91)

Another problem is that Governments have on occasion placed the dispute resolution system in impossible situations. At least two such situations emerge from the above discussion. The US justification for steel import restrictions is based on an alleged national security. National security is self-determined. Others are charging that based on the facts, protecting steel is a safeguard action designed -not a defence of national security - to permit the US to maintain a certain level of national steel production capacity. The decision as to the purpose of the restrictive measure will place the dispute settlement process between a rock and a hard place. If the US position holds, any country could claim a restriction was necessary in almost any product to protect national security (Swedish army boots or Japanese rice). If the ruling is that this is not a question of national security but a safeguard measure, the measure would be time-bound, require proof of injury, compensation for the restricted countries, and possibly retaliation. Should the US lose, President Trump may consider this to be such an affront that he makes good his threat to withdraw from the WTO. There could be an unravelling of WTO disciplines as countries find cause to protect for purposes of national security. A 
second example relates to the continuing treatment of China as a non-market economy. The WTO challenge by China to the US, EU, Japan and others and its claim that it should be treated as a market economy places the dispute resolution system in a situation of determining what constitutes a nonmarket economy. In both instances the decision is a policy decision to be taken by governments. It is somewhat perverse that the US is heavily involved in both confrontations when it is the US that has accused the Appellate Body of over-stepping the mark with determinations that should be left to governments.

\subsection{Blocking Proceedings}

A worrisome recent development is the US refusal to agree to the appointments of new Appellate Body members as the term of sitting members expires. If this matter is not resolved, the sevenmember Appellate Body will have only three members in the coming months which is the minimum needed to consider an appeal. It will cease to be operational at the end of 2019 when two more vacancies arise. This constitutes a major systemic risk if it leads to unilaterally determined retaliation in cases where dispute settlement panel reports are not adopted. With not even three of the seven members of the Appellate Body appointed, as will most likely be the case in the near future, the WTO dispute settlement will become non-operational. A further criticism relates to the length of Appellate Body rulings. The US delegation has claimed the Appellate Body has ignored mandatory requirement to complete appeals in no more than 90 days. The appeals are always complex and the Appellate Body resources are limited.

\section{CONCLUSION}

A rules-based trading system centred on the WTO is fundamental to Australia's interests ... many aspects of our world are inconceivable without the certainty and predictability inherent in a system based on rules.' (Australian Government 2017 p. 82)

At the most fundamental level the challenge facing the WTO is the inability of governments to function within the boundaries of the consensus based laws that they have created over 70 years. The WTO remains an effective instrument of international cooperation and guarantor of the rule of law. Its alleged institutional challenges reside in the inability of member countries to reconcile their diverging interests. The WTO is not responsible for rising protectionism and its mechanisms to cope with the fallout are constrained by the nature and the boundaries of the agreements into which its Members have voluntarily entered. The WTO should not be judged against standards which it was never designed to meet. A more realistic view may in future be taken of its capabilities and limitations.

\section{REFERENCES}

Australian Department of Foreign Affairs and Trade 2017, Foreign Policy White Paper: Opportunity Security Strength, Canberra, November.

Bown Chad P., Steiger Robert W. and Sykes Alan O. 2017, 'Multilateral or bilateral trade deals? Lessons from history', Chapter 14 in Chad Bown ed., Economics and Policy in the Age of Trump, Centre for Economic Policy Research 33 Great Sutton Street London, EC1V 0DX. 
Bown Chad P. 2017, 'Aluminium, Lumber, Solar: Trump's Stealth Trade Protection', Peterson Institute for International Economics, Policy Brief, Washington, June.

Carmichael Bill 2005, 'Trade Policy at the Cross-Roads' Asia Pacific School of Economics and Government, Pacific Economic Paper No. 351

Garnaut Ross 2003, 'A case study in unilateral trade liberalisation' in Jagdish Bhagwati (Editor),_Going Alone: The Case for Relaxed Reciprocity in Freeing Trade, (MIT Press).

GATT 1949, Contracting Parties Third Session, Summary Records of the Twenty Second Meeting, CP.3/SR22 - II/28, Annecy, June

Grubel H. G. and Lloyd P. J. 1971, 'The Empirical Measurement of Intra-Industry Trade', Economic Record, vol. 47, issue 120, 494-517.

Guevara Che (1964), Speech delivered March 25, 1964 at the plenary session of the United Nations Conference on Trade and Development (UNCTAD) https://www.marxists.org/archive/guevara/1964/03/25.htm

Hofmann Claudia, Osnago Alberto, Ruta Michele 2017, 'Horizontal Depth A New Database on the Content of Preferential Trade Agreements', Policy Research Working Paper 7981, Trade and Competitiveness Global Practice Group, World Bank, Washington, February.

Horn, H., Mavroidis, P. C. and Sapir, A. 2010, "Beyond the WTO? an anatomy of EU and US preferential trade agreements", The World Economy 33(11): 1565-1588.

Krueger Anne 1997, "Trade Policy and Economic Development: How We Learn", American Economic Review, Vol. 87, No. 1.

Lamy Pascal 2002, 'The WTO's contribution to global governance', Chapter 2 in Gary P. Sampson ed. The WTO and Global Governance: Future Directions, United Nations University Press.

Lighthizer Robert 2017, 'Opening Plenary Statement to the WTO 11th Ministerial Conference', Buenos Aires, Argentina, December

Lloyd Peter 2012, 'The Role of Developing Countries in Global Governance', The Singapore Economic Review (SER), World Scientific Publishing Co. Pte. Ltd., vol. 57(02)

Macron Emanuel 2018, Keynote Address, OECD Ministerial Meeting, Paris 30 May. https://ustr.gov/sites/default/files/files/Press/Reports/2018/AR/2018\%20Annual\%20Report\%20FIN

$\underline{\text { AL.PDF }}$

Monroe Marylin 1962, 'Happy Birthday Mr. President', May 19, https://genius.com/Marilyn-monroehappy-birthday-lyrics

Productivity Commission 2017, 'Rising protectionism: challenges, threats and opportunities for Australia', Research Paper, July.

Rattigan, G.A. 1986, Industry Assistance: The Inside Story, Melbourne University Press, Melbourne. 
Ross Wilbur 2017, 'Free and Fair Trade for American Workers and Businesses,' White House Blog, April 13.

Sampson G. P. and Snape R. H. 1985, 'Identifying the Issues in Trade in Services', The World Economy, Volume 8, Number 2, June.

Sampson Gary P. 2005, The World Trade Organization and Sustainable Development, United Nations University Press, Tokyo, New York, Paris

Snape, R.H. Gropp L. and Luttrell T. 1998, Australian Trade Policy 1965-1997: A Documentary History, Allen \& Unwin, Sydney.

Stewart Terence P. 2018, The Broken Multilateral Trade Dispute System, Asia Society Policy Institute February 7.

The Straits Times 2017, 'What we know so far about the US-China dispute over trade practices, intellectual property', Augusthttp://www.straitstimes.com/world/united-states/what-we-know-sofar-about-the-us-china-dispute-over-intellectual-property

Trump Donald 2016, 'Donald Trump threatens to pull US out of WTO', Financial Times, Geoff Dyer, Washington July 24. https://www.ft.com/content/d97b97ba-51d8-11e6-9664-e0bdc13c3bef

Trump Donald 2017a, 'Steel stocks spike as Trump says he is considering using quotas, tariffs to deter dumping', CNBC, Evelyn Cheng, 13 July 2

https://www.cnbc.com/2017/07/13/trump-says-he-is-considering-using-quotas-tariffs-to-deter-

steel-dumping.html

Trump Donald 2017b, 'Trump administration goes after China over intellectual property',

Washington Post, August, https://www.washingtonpost.com/gdpr-

consent/?destination=\%2fnews $\% 2$ fwonk $\% 2$ fwp $\% 2 \mathrm{f} 2017 \% 2 \mathrm{f0} \% 2 \mathrm{f} 14 \% 2 \mathrm{ftrump}$-administration-goesafter-china-over-intellectual-property-advanced-technology\%2f\%3f\&utm term=.a687fefabb8e

Trump Donald 2018a, 'Trade wars are good, and easy to win', Business News, March 2 https://www.reuters.com/article/us-usa-trade-trump/trump-tweets-trade-wars-are-good-and-easyto-win-idUSKCN1GE1E9

Trump Donald 2018b, Remarks by President Trump, Vice President Pence, Members of Congress, and Members of the Cabinet in Meeting on Trade Infrastructure and Technology, Issued by the Whitehouse February 13, 2018 https://www.whitehouse.gov/briefings-statements/remarkspresident-trump-vice-president-pence-members-congress-members-cabinet-meeting-trade/

United States Government 2018, President Trump, Vice President Pence, Members of Congress, and Members of the Cabinet in Meeting on Trade, Issued on: February 13, https://www.whitehouse.gov/briefings-statements/remarks-president-trump-vice-president-pencemembers-congress-members-cabinet-meeting-trade/

This article is protected by copyright. All rights reserved 
US Government 2001, Message from the President of the United States: 2001 Trade Policy Agenda and 2000 Annual Report on the Trade Agreements Programme, US Government Printing Office, Washington 2001

USTR 2017, Crystalline Silicon Photovoltaic Cells (Whether or not Partially or Fully Assembled into Other Products) Investigation No. TA-201-75, Volume 1: Determination and views of the commissioners, Publication 4739 November.

USTR 2018, Trade Policy Agenda and 2017 Annual Report, Part II Agreements and Negotiations. https://ustr.gov/about-us/policy-offices/press-office/reports-and-publications/2018/2018-tradepolicy-agenda-and-2017,

Wolf Martin 2002, 'What the World Needs from the Multilateral Trading System', in ed. Gary P. Sampson, The Role of the WTO in Global Governance, United Nations University Press, Tokyo, New York, Paris.

Wolff Alan 2018, 'WTO accession has served as a key engine for economic transformation', Address to the Astana Economic Forum in Kazakhstan on 18 May.

WTO 2001, Report of the Working Party on the Accession of China, 10 November, WT/MIN(01)/3, WTO, Geneva.

WTO 2002, The Legal Texts of the Results of the Uruguay Round of Multilateral Negotiations, WTO Secretariat, Rue de Lausanne 154, $\mathrm{CH}-1211$ Genève 21, Switzerland https://docs.wto.org/gtd/WTOlegaltexts/Legal texts e.pdf

WTO 2011, The WTO and Preferential Trade Agreements: from co-existence to coherence, World Trade Report, Geneva, Switzerland

WTO 2013, Special and Differential Treatment Provisions in WTO Agreements and Decisions, Note by the Secretariat, WT/COMTD/W/196

WTO 2018, Trade Policy Review: China, WTO Secretariat, Geneva, Switzerland, July. https://www.wto.org/english/tratop e/tpr e/s375 e.pdf

Wu Mark 2016, 'China, Inc. - to Global Trade Governance', Harvard International Law Journal Volume 57 , Number 2, Spring.

\section{ENDNOTES}

\footnotetext{
${ }^{1}$ The term multilateral (cf. international) trading system is traditionally used to describe the GATT or WTO trading system as not all countries are members. The text of the revised GATT-1947 is part of the total texts of the WTO agreements. (WTO 2002)

${ }^{2}$ It is necessary to be selective in choosing the issues as the challenges are numerous. Also, trade policy can change rapidly so I have tried to concentrate on the more systemic issues. Given the pivotal role of the United States in recent trade skirmishes, disproportionate (but in my view an appropriate) attention is paid to US trade policy.
} 


\footnotetext{
${ }^{3}$ The scope and depth of the GATT system was expanded to include agriculture, services, intellectual property, investment, textiles, improved dispute settlement procedures and many other agreements.

${ }^{4}$ For an excellent overview of this period see Garnaut 2003.

${ }^{5}$ Although the terms 'regional trade agreement' (RTA) and 'free trade agreements' (FTA) are widely used, this article adopts the more generic term Preferential Trade Agreement as does the WTO (2011). PTAs encompass both free trade agreements and customs areas. Three quarters of PTAs are FTAs and only half of RTAs are regional. WTO (2011 p 6),

${ }^{6}$ Along with Australia, the RCEP includes the ASEAN states and countries with PTAs with ASEAN. It includes China but not the US. RCEP countries account for half the world's population, 30 per cent of global GDP and a quarter of world exports. These negotiations are well advanced.

${ }^{7}$ Maintaining protectionist measures against imports that are inputs into the final output of a GSC makes defies logic. Benefits flow from cheaper inputs. Reciprocity is not required.

${ }^{8}$ The measures are listed in WTO 2017, p.129, Hoffman et.al. 2017, and Horn et. al. 2010.

${ }^{9}$ For a detailed discussion of what special and differential treatment entails see Lloyd 2012.

${ }^{10}$ The WTO Antidumping Agreement deals with dumping, and Section 731 of the US Tariff Act of 1930 is the main US antidumping law.

${ }^{11}$ The benchmark is typically either: the price for which the foreign firm sells the same good in its home market, the price for which the foreign firm sells the same good in a third market, or a constructed measure of the foreign firm's costs.

${ }^{12}$ The Subsidies Agreement is the relevant agreement at the WTO and Section 701 of the US Tariff Act of 1930 for the United States.

${ }^{13}$ Section 201 of the Trade Act is the relevant law in the US. For the WTO it is the Agreement on Safeguards.

${ }^{14}$ For the WTO, GATT Article XXI 'Security Exceptions' is the relevant article. The relevant law in the US is Section 232 of the Trade Expansion Act of 1962.

${ }^{15}$ Financial times, 'Chinese voices that oppose reform grow louder', Financial Times, 10 December 2006. Interview by the Financial Times (10 December 2006)

${ }^{16}$ Section 337 of the Tariff Act of 1930

17 Section 301 of the Trade Act
} 


\section{University Library}

\section{- M M I N E R VA A gateway to Melbourne's research publications}

Minerva Access is the Institutional Repository of The University of Melbourne

Author/s:

Sampson, GP

Title:

Challenges Facing the World Trade Organization: An Overview

Date:

2018-12-01

Citation:

Sampson, G. P. (2018). Challenges Facing the World Trade Organization: An Overview. AUSTRALIAN ECONOMIC REVIEW, 51 (4), pp.453-473. https:// doi.org/10.1111/1467-8462.12301.

Persistent Link:

http://hdl.handle.net/11343/284864 